\title{
CONSTRUCTION FACTORS THAT CAUSING REWORKS IN DOWNSTREAM ACTIVITIES DUE TO OVERLAPPING
}

\author{
Hossam H. Mohamed \\ Professor, Construction Engineering and Utilities Department \\ Zagazig University, Zagazig, Egypt \\ Ahmed H. Ibrahim \\ Professor, Construction Engineering and Utilities Department \\ Zagazig University, Zagazig, Egypt \\ Asmaa A. Soliman * \\ Assistant Lecturer of Construction Engineering, \\ Higher Technological Institute (HTI), Egypt \\ *Corresponding Author
}

\begin{abstract}
Reworks due to activities overlapping have both direct and indirect effects on the performance of construction projects. To reduce the impact of reworks there is a need to understand their basic reason for their existence. This paper aims to identify the top changes that affecting upstream production rate and causing reworks in downstream activities. These changes were identified through three stages. The first stage 23 changes were collected from a past literature review and were divided into three major categories: designer, contractor, and owner changes. 100 effective interviews were conducted and their results are employed. In the second stage, the 23 changes were then ranked from the most significant to the less significant. The third stage, the 80/20 rule applied to the changes identified to get the eight top important changes. The result shows the top important eight factors are Lack of coordination and poor communication, The contractor instruction to modify a design, Non-compliance with the specification, The owner instruction to modify a design, Incomplete design at the time of tender, Poor planning and coordination of resources, Errors made in the contract documentation and Lack of experience and knowledge of the design and construction process.
\end{abstract}

Keywords: Fast Tracking, Activities Overlapping, Rework Time, Construction Schedule, AHP 
Cite this Article: Hossam H. Mohamed, Ahmed H. Ibrahim and Asmaa A. Soliman, Construction Factors That Causing Reworks in Downstream Activities Due to Overlapping, International Journal of Civil Engineering and Technology (IJCIET), 12(2), 2021, pp. 19-32.

https://iaeme.com/Home/issue/IJCIET?Volume=12\&Issue=2

\section{INTRODUCTION}

Rework in construction projects is defined as Activities in the field that have to be done more than once in the field, or activities that remove work previously installed as part of the project regardless of source, where no change order has been issued and no change of scope has been identified by the owner (Jason and James, 2018). Construction project time overrun is defined as an addition of time further than the agreed contractual time at the tender stage. Rework can lead to a considerable addition of a project's time and cost overrun, especially during the construction stage. The effect of delays or time overruns for the contractor included increased costs, reduced profit margin, and battered reputation (Eze and Idiake, 2015).

\section{LITERATURE REVIEW}

Resource-constrained project scheduling is the process of constructing a project schedule within the limited amount of resources available. It requires the examination of the possible unbalanced use of resources over time to resolve over-allocation (the so-called resource conflicts) when more resources are required than available. When more resources such as machines or people are needed than there are available, these activities will have to be rescheduled concurrently or even sequentially to resolve the resource constraints. Hence the resource-constrained project scheduling is the process of resolving these resource conflicts under different scheduling objectives (Vanhoucke, 2012). Abeku et al., (2017) mentioned that the factors that causing rework during construction are poor management and employee training, the low skill level of sub-contractors, lack of supervision and on-site inspection damage due to carelessness, poor planning, and coordination of site resources, and poor workmanship and use of materials. The accuracy of the drawings, the number of design errors, omissions, and ambiguities within the plans and specifications that affect the quality of the facility are identified according to Musa and Obaju (2016). Dosumu et al. (2017) concluded that errors in contract documents are frequently caused by clients' change of design and specifications, lack of adequate time to prepare contract documents use of inexperienced designers to prepare contract documents, oversight, negligence, and laziness. Fast-tracking can result in rework and increased risk. This approach can require work to be performed without completed detailed information, such as engineering drawings. It results in a trading cost for time and increases the risk of achieving the shortened project schedule (PMBOK, 2004). Sen et al., (2018) concluded that the lack of experience and knowledge of design and construction process, poor quality of construction technique, and poor use of advanced engineering are more responsible for rework in the construction process. Enshassi et al., (2017) indicated that the most important rework causes that have a significant impact on project performance are: attempt to fraud, competitive pressure, ineffective management, schedule pressure, and the absence of job security.

A summary of a huge number of different scheduling objectives and the studies of modeling construction schedule was developed and reproduced in Table 1. These factors which are gathered are forty one which affects the construction schedule. The effects of rework include: Lost of profit by the contractor, extra project cost to the client, schedule delay, reduced project performance, and changed project outlook (Love et al., 2004). 
Table 1 A summary of factors affecting construction schedule according to different authors

\begin{tabular}{|c|c|c|c|}
\hline Authors & year & Factors Affecting Construction Schedule & No. of Factors \\
\hline $\begin{array}{l}\text { Jing Liu and Ming } \\
\text { Lu, [7] }\end{array}$ & 2018 & $\begin{array}{l}\text { 1) Crew Limits, 2) Technical Precedence } \\
\text { Relationships, 3) Predefined Deadline, } \\
\text { 4)Multiple Activity Modes, 5) Material } \\
\text { Logistics, 6) Material Inventory and Material } \\
\text { Supply 7) Crew Availability, 8) Material } \\
\text { Demand of Each Activity and 9) Crew } \\
\text { Resource Demand of Each Activity. }\end{array}$ & 9 \\
\hline $\begin{array}{l}\text { RazaviAlavi and } \\
\text { AbouRizk, [12] }\end{array}$ & 2017 & $\begin{array}{l}\frac{\text { Site layout planning has an effect on }}{\text { construction schedules: 1) Costs for }} \\
\text { Mobilization and Demobilization of Facilities, } \\
\text { 2) Transportation Cost of material, workers and } \\
\text { Equipment and 3) Rent Cost of off-Site Storage }\end{array}$ & 3 \\
\hline Arashpour et al., [2] & 2015 & $\begin{array}{c}\text { Cash Constraints: 1) Direct Capacity Balancing, } \\
\text { 2) Partial Skill Chaining, 3) Closed Skill } \\
\text { Chains, 4) Hybrid Cross-Training, and 5) Full } \\
\text { Cross-Training. }\end{array}$ & 5 \\
\hline El-Abbasy, [5] & 2015 & $\begin{array}{c}\text { Finance-based scheduling: 1) Interest Rate, 2) } \\
\text { Credit Limits, 3) Establishing Bank Overdrafts. } \\
\text { Cash Flow: 1) Project Direct Cost } \\
\text { Disbursement, 2) Expenses of Overheads, 3) } \\
\text { Taxes, 4) Mobilization, and 5) Bond at Period. } \\
\text { Resources: 1) The Total Amount of Resources, } \\
\text { 2) Total Daily Resource Fluctuations, 3) } \\
\text { Maximum Resource Demand During The } \\
\text { Entire Project Duration and 4) The Total } \\
\text { Number of Idle and Non-productive Resource } \\
\text { Days. }\end{array}$ & 12 \\
\hline Pakgohar, [15] & 2014 & $\begin{array}{c}\text { Single Project Scheduling:1) Single-Mode or } \\
\text { Multi-Mode, 2) Multiple Renewable Resource } \\
\text { and (Multiple) Non-Renewable Resource, 3) } \\
\text { Precedence Relations, 4) Precedence } \\
\text { Constraints }\end{array}$ & 4 \\
\hline Chen and Weng, [3] & 2009 & $\begin{array}{l}\text { A project consists of a set of interrelated } \\
\text { activities. Each activity: 1) Execution Modes, } \\
\text { 2) Activity Duration, 3) Activity Cost, 4) } \\
\text { Precedence Relationship, 5) Resource } \\
\text { Requirements, 6) Overlap, 7) Interruption, 8) } \\
\text { State of The Activity. }\end{array}$ & 8 \\
\hline \multicolumn{3}{|c|}{ Total Factors Affecting Construction Schedule } & 41 \\
\hline
\end{tabular}

Upstream work should there be a change in upstream information. The information exchanged is also associated with a level of uncertainty depending on the type of upstream activity in question. Future upstream information modifications require to rework in the downstream activity to address the changes of the initial information based on which the downstream has started. The resulting rework usually consumes resources (e.g. time and money) and is disruptive to the flow of the downstream work.

The following sections present the research steps to achieve the objectives. An exploratory survey was carried out to identify factors affecting upstream production rate and causing reworks in downstream activities. 
- The different causes of changes affecting upstream production rate and causing reworks in downstream activities were gathered through a comprehensive literature review.

- A questionnaire survey was conducted to identify the most important factors of those causing reworks in downstream activities depending on the overlapping degree.

The objectives of this research are outlined as follows:

- Identifying the different factors affecting upstream Production rate and causing reworks in downstream activities

- Ranking these factors according to their relative importance to find out the most important factors

- Develop practical recommendations and guidelines to time reworks effect in downstream activities.

\section{QUESTIONNAIRE SURVEY}

In this survey, thirty-nine (39) factors affecting upstream production rate and causing reworks in downstream activities as shown in Table 2. Then, a brainstorming session was conducted to reduce the number of these factors and get the most important factors and remove the repeated factors. Three main categories (designer, owner, and contractor factors) as shown in Table 3, the selected twenty-three (23) factors were ranked according to their relative importance to find out the most important factors of causing factors affecting upstream production rate and causing reworks in downstream activities.

Table 2 Summary of Changes Arising in Upstream Activities and Causing Reworks in Downstream Activities According to Different authors (Soliman, 2021)

\begin{tabular}{|c|c|c|c|}
\hline Authors & year & $\begin{array}{c}\text { Changes arising in upstream activities and } \\
\text { causing rework in downstream activity }\end{array}$ & $\begin{array}{c}\text { No. of } \\
\text { Factors }\end{array}$ \\
\hline $\begin{array}{c}\text { Aman Sen, et al., } \\
\text { [2] }\end{array}$ & 2019 & $\begin{array}{c}\text { 1) Lack of experience and knowledge of design } \\
\text { and construction process, 2) Poor quality of } \\
\text { construction technique, 3) Poor use of } \\
\text { advanced engineering, 4) Adverse natural } \\
\text { condition, 5) Lack of use of advanced } \\
\text { mechanical equipment. }\end{array}$ & 5 \\
\hline Enshassi et al., [8] & 2017 & $\begin{array}{c}\text { 1) Competitive pressure / low contract value, } \\
\text { 2) Ineffective management and decision- } \\
\text { making, 3) Schedule pressures, 4) The absence } \\
\text { of job security, 5) Competitive pressure / low } \\
\text { contract value, 6) An insufficient skill level, 7) } \\
\text { Emergency conditions, 8) Poor quality system, } \\
\text { 9) Disturbances in personnel planning and 10) } \\
\text { Adulterated Materials }\end{array}$ & 10 \\
\hline Wakefield et \\
al.,[21] & 2014 2) external & 10 \\
\hline & $\begin{array}{c}\text { 1) Contractor Field Management, 2) } \\
\text { environment, 3) contract management, 4) } \\
\text { subcontractor management, 5) design } \\
\text { management, 6) project communication } \\
\text { management, 7) project plan changes, 8) } \\
\text { changes for quality improvement 9) project } \\
\text { scope management, 10) client management and } \\
\text { 11) project process management }\end{array}$ & 11 \\
\hline
\end{tabular}




\begin{tabular}{|c|c|c|c|}
\hline Love and Li, [12] & 2000 & $\begin{array}{c}\text { 1) Errors, 2) Omissions, 3) Failures, 4) } \\
\text { Damage, and 5) Change Orders. }\end{array}$ & 5 \\
\hline $\begin{array}{c}\text { Mohammad and } \\
\text { Majid,[14] }\end{array}$ & $2019 \quad \begin{array}{c}\text { 1) Improper handling of material } \\
\text { and delivery, 2) Unclear project management } \\
\text { Process, 3) Poor sub-contractor management, } \\
\text { 4) Poor design constructability or } \\
\text { misunderstanding of the design, 5) Precedence } \\
\text { Constraints, 6) The need to categorize the } \\
\text { complicated operations, 7) Lack of standard } \\
\text { method statements, 8) Poor clear contracting } \\
\text { with sub-contractors and executive staff. }\end{array}$ & 8 \\
\hline \multicolumn{2}{|c|}{ Total Factors Affecting Construction Schedule } & 39 \\
\hline
\end{tabular}

Table 3 Changes Arising in Upstream Activities and Causing Reworks in Downstream Activities and its Category (Soliman, 2021)

\begin{tabular}{|c|c|c|}
\hline $\begin{array}{l}\text { Change } \\
\text { No. }\end{array}$ & $\begin{array}{c}\text { Changes of Predecessor Activities that } \\
\text { Causing Reworks in Downstream } \\
\text { Activities Due to Period Overlapping }\end{array}$ & Changes Category \\
\hline F1 & Incomplete Design at the time of tender. & \multirow{8}{*}{ Designer Related Changes } \\
\hline $\mathrm{F} 2$ & Poor Coordination of design. & \\
\hline $\mathrm{F} 3$ & $\begin{array}{l}\text { The design change is initiated due to } \\
\text { financial and economic changes. }\end{array}$ & \\
\hline $\mathrm{F} 4$ & $\begin{array}{l}\text { Omissions of activity or task from the } \\
\text { contract documentation. }\end{array}$ & \\
\hline F5 & Errors made in the contract documentation. & \\
\hline F6 & $\begin{array}{l}\text { Insufficient time to prepare contract } \\
\text { documentation. }\end{array}$ & \\
\hline F7 & $\begin{array}{l}\text { Inadequate client brief to prepare detailed } \\
\text { contract documentation. }\end{array}$ & \\
\hline $\mathrm{F} 8$ & Ineffective use of information technologies. & \\
\hline F9 & $\begin{array}{l}\text { The contractor instructed to modify a } \\
\text { design }\end{array}$ & \multirow{8}{*}{ Contractor Related Changes } \\
\hline F10 & $\begin{array}{l}\text { The contractor instruction to modify } \\
\text { construction methods }\end{array}$ & \\
\hline F11 & Non-compliance with the specification. & \\
\hline F12 & Machine breakdown and defects & \\
\hline F13 & $\begin{array}{l}\text { Poor planning and coordination of } \\
\text { resources. }\end{array}$ & \\
\hline F14 & $\begin{array}{l}\text { Omission errors some activity or task by } \\
\text { construction personnel. }\end{array}$ & \\
\hline F15 & The unqualified workforce in the project & \\
\hline F16 & Lack of training and experience. & \\
\hline F17 & $\begin{array}{l}\text { Lack of coordination and poor } \\
\text { communication. }\end{array}$ & \multirow{2}{*}{ Owner Related Changes } \\
\hline F18 & The owner instructed to modify a design & \\
\hline
\end{tabular}




\begin{tabular}{|c|c|c|}
\hline F19 & $\begin{array}{l}\text { Lack of experience and knowledge of the } \\
\text { design and construction process. }\end{array}$ & \\
\hline F20 & $\begin{array}{l}\text { Lack of funding allocated for site } \\
\text { investigations. }\end{array}$ & \\
\hline $\mathrm{F} 21$ & Lack of client involvement in the project. & \\
\hline F22 & $\begin{array}{l}\text { Insufficient time and money spent on the } \\
\text { briefing process. }\end{array}$ & \\
\hline $\mathrm{F} 23$ & $\begin{array}{l}\text { Lack of Expenditure for preparing contract } \\
\text { documentation }\end{array}$ & \\
\hline
\end{tabular}

\subsection{Sample Size}

According to Easterby-Smith et al. (2002) [1] which were using Eq. (1) to compute the required sample size for unlimited population:

$$
n=\frac{2500}{E^{2}}
$$

Where,

$\mathrm{n}$ : is the required sample size for infinite population,

E:is acceptable standard error is less than5\% which used as percent.

\subsection{Data Analysis}

One hundred and thirty questionnaires (see appendix) were administered to professionals and experts in different construction projects. A total of one hundred questionnaires representing $76.92 \%$ of the total questionnaires administered were returned. Table 4 shows details of questionnaires administered and the rate of return. The respondents' job titles were classified into three categories in construction projects. The first category from a designer point of view owner represented $73.23 \%$, the second category from a contractor point of view (cost estimators, civil engineers, and project managers) represented $87.33 . \%$ and the third category from an owner point of view represented $77.5 \%$. Figure 1 illustrates the number of each category. The respondents to the questionnaire were classified according to their experience in Table 5 and Figure 2. A closer inspection to Figure 2 clearly shows that about $14 \%$ of the respondents have experience Less than 10 years, around $48 \%$ have experienced greater than or equals to 10 years and less than 20, around $30 \%$ have experienced greater than or equal 20 years and less than 30 and finally, $8 \%$ of respondents have experienced greater than or equals to 30 years

Table 4 Details of Questionnaires Administered and the Rate of Return (Soliman, 2021)

\begin{tabular}{|c|c|c|c|}
\hline $\begin{array}{c}\text { Professionals } \\
\text { and Experts }\end{array}$ & $\begin{array}{c}\text { No. of } \\
\text { Questionnaires }\end{array}$ & $\begin{array}{c}\text { No. of Questionnaires } \\
\text { Returned }\end{array}$ & $\begin{array}{c}\text { \% Returned } \\
\text { Rate }\end{array}$ \\
\hline Designer & 30 & 22 & $73.23 \%$ \\
\hline Contractor & 60 & 47 & $87.33 \%$ \\
\hline Owner & 40 & 31 & $77.5 \%$ \\
\hline Total & 130 & 100 & $76.92 \%$ \\
\hline
\end{tabular}




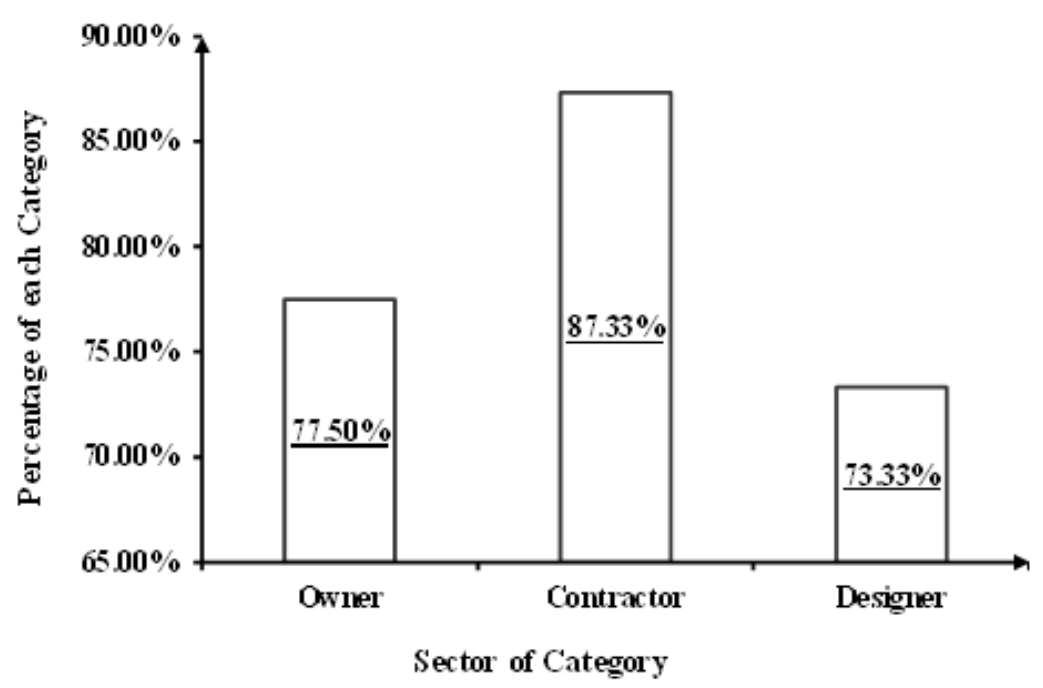

Figure 1 Classification of Respondents Based on Their Job Title Category

Table 5 Classification of the Surveyed Experts Based on Their Experience

\begin{tabular}{|c|c|c|c|c|}
\hline Experience Practicing & Owner & Contractor & Designer & Total \% \\
\hline Less than 10 years & 6 & 6 & 2 & 14 \\
\hline Greater than or Equals to 10 years and Less than 20 & 10 & 21 & 17 & 48 \\
\hline Greater than or Equal 20 years and Less than 30 & 4 & 15 & 11 & 30 \\
\hline Greater than or Equals to 30 years & 2 & 5 & 1 & 8 \\
\hline Total & 22 & 47 & 31 & 100 \\
\hline
\end{tabular}

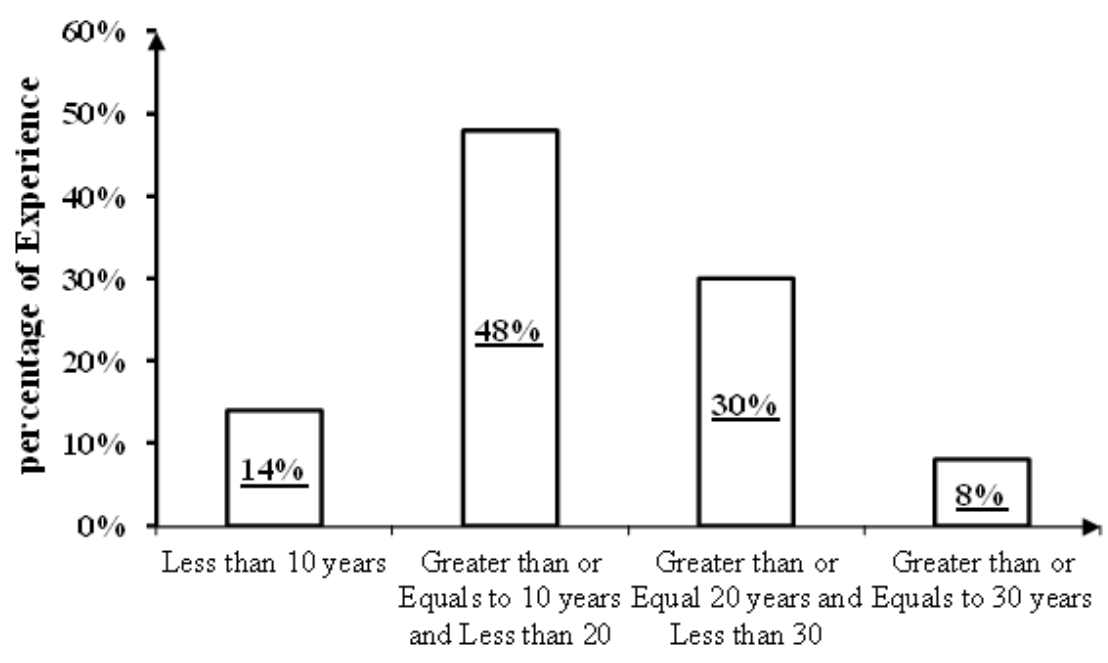

\section{Experience Practicing}

Figure 2 Classification of the Surveyed Experts Based on Their Experience (Soliman, 2021)

\subsection{Top Effective Upstream Changes}

The respondents have inserted two scores in front of each factor in each percentage degree of overlapping between activities. First, the degree of impact of each factor causing reworks in 
downstream activities. Second, the probability of occurrence of Rework for each factor on downstream activities, then calculate importance index for the previously identified twentythree changes, finally, all changes are ranked in descending order according to their importance index according to Eq.2, Eq.3 Eq.4 and Eq.5.

Total Score of Rework Frequency

$=$ Rework Frequency of each problem $=\sum_{i=1}^{n}(\mathrm{Fr})$

Total Score of Severity

Severity of each factor $=\sum_{i=1}^{n}(S I)$

Rework Frequency Index $\left(F_{I}\right)$

$=\frac{\text { Total Score Rework Frequency }}{\text { No. of Respondents }(N) \times 10}$

Severity Index $\left(S_{R}\right)=\frac{\text { Total Score of Severity }}{\text { No. of Respondents }(N) \times 10}$

Importance Index $=(F I) *(S I) * 100$

Where:

$\mathrm{N}$ : is the total number of respondents to each factor, $(\mathrm{N}=100)$

10: represented the upper scale of the measurement.

The analysis also shows that the weight of all categories. Where (Owner changes) represented $25.80 \%$ followed by (Contractor changes) represented $41.93 \%$ and finally (Designer changes) represented $32.25 \%$ as shown in Figure 3.

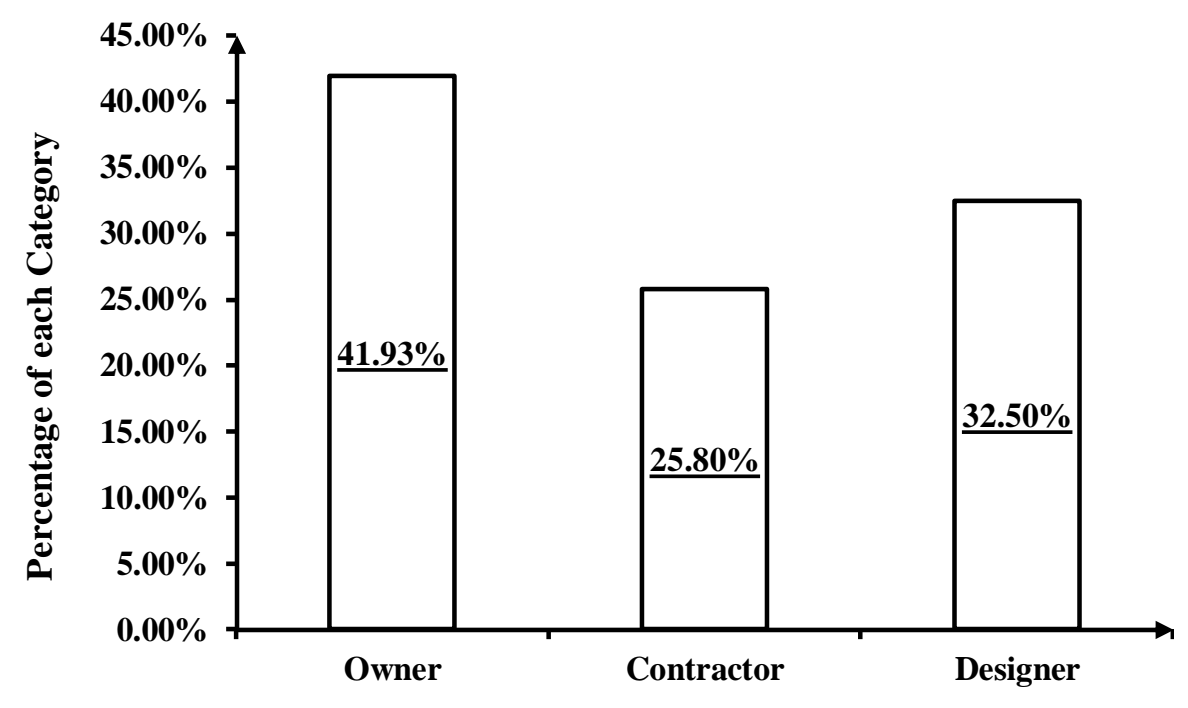

Categories of Rework Problems

Figure 3 Categories of the Changes that Causing Reworks in Downstream Activities (Soliman, 2021)

\section{RESULTS}

Based on the analysis and review of the construction industry surveyed experts' opinion and according to Pareto Principle, which states that 80 percent of the changes come from 20 percent of the causes, to select a certain number of changes which represent all changes and also these changes are the changes with the highest importance indexes. The minimum number of changes 
considerable according to Pareto $=20 \% * 24 \approx 5$ changes. The top eight changes and their importance indices are as follows: Lack of Coordination and Poor Communication were ranked in the first position with an (R.II) $33.87 \%$ as the most important cause downstream reworks. The contractor instruction to modify a design was ranked in the second position with an (R.II) $25.65 \%$. Non-compliance with specification was ranked in the third position with an (R.II) $23.84 \%$. The owner instruction to modify a design is in the fourth position with an (R.II) 21.66 $\%$. Incomplete Design at The time of Tender was ranked in the fifth position with an (R.II) $21.58 \%$.Poor planning and coordination of Resources in the sixth position with an (R.II) 21.20 $\%$. Errors made in the contract documentation in the seventh position with an (R.II) $20.94 \%$. Lack of experience and knowledge of the design and construction process in the eighth position with an (R.II) $20.72 \%$ as shown in Figure 4

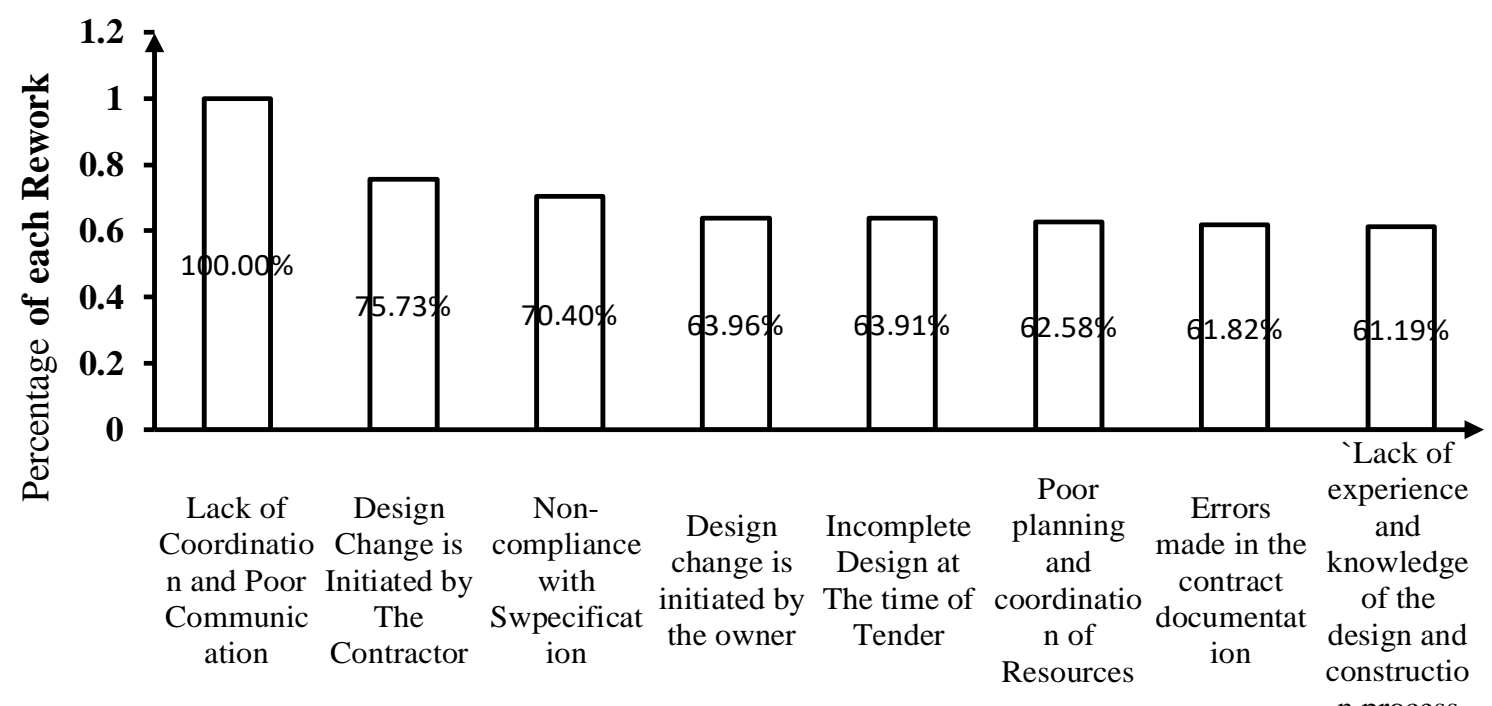

Figure 4 Top Important Eight Changes That Causing Reworks in Downstream Activities (Soliman, 2021)

All changes have been ranked according to their important index as shown in Table 6. Also, the result showed that instead of eight changes, two changes were only considered under designer changes. Also instead of nine changes, three changes were only considered under contractor changes. Finally, it demonstrates that the weight of designer changes, contractor changes, and changes related to owner changes are $25 \%, 37.5 \%$, and $37.5 \%$ respectively as shown in Table 7.

Table 6 Changes Causing Rework in Downstream Activities Before and After Ranking, (Soliman, 2021)

\begin{tabular}{|c|c|c|c|c|}
\hline \multirow{2}{*}{$\begin{array}{c}\text { Change } \\
\text { Category }\end{array}$} & \multicolumn{2}{|c|}{$\begin{array}{c}\text { All Changes } \\
\text { Before Ranking }\end{array}$} & \multicolumn{2}{c|}{$\begin{array}{c}\text { Changes After } \\
\text { Ranking }\end{array}$} \\
\cline { 2 - 5 } & Sum & Weight & Sum & Weight \\
\hline Designer & 8 & $33.23 \%$ & 2 & $25 \%$ \\
\hline Contractor & 9 & $37.5 \%$ & 3 & $37.5 \%$ \\
\hline Owner & 7 & $29.17 \%$ & 3 & $37.5 \%$ \\
\hline Total & $\underline{24}$ & $\underline{100} \%$ & $\underline{8}$ & $\underline{100} \%$ \\
\hline
\end{tabular}


Construction Factors That Causing Reworks in Downstream Activities Due to Overlapping

Table 7 The calculated important index for all changes causing Reworks in Downstream Activities

\begin{tabular}{|c|c|c|c|c|c|c|c|c|c|c|c|c|c|c|}
\hline \multirow{2}{*}{$\begin{array}{l}\text { Factor } \\
\text { No. }\end{array}$} & \multirow{2}{*}{$\begin{array}{l}\text { Changes Causing Revwork in Downstream } \\
\text { Actirities }\end{array}$} & \multirow{2}{*}{ Category } & \multicolumn{5}{|c|}{$\mathrm{R} 2 \rightarrow \mathrm{R} 100$} & \multirow{2}{*}{\begin{tabular}{|c} 
Total \\
Responses \\
(I)
\end{tabular}} & \multirow{2}{*}{$\begin{array}{c}\text { Total } \\
\text { Score of } \\
\text { Ser erity }\end{array}$} & \multirow{2}{*}{$\begin{array}{c}\text { Ser erity } \\
\text { Index }\end{array}$} & \multirow{2}{*}{\begin{tabular}{|c} 
Total Score \\
of \\
Frequency
\end{tabular}} & \multirow{2}{*}{$\begin{array}{c}\text { Frequency } \\
\text { Index }\end{array}$} & \multirow{2}{*}{$\begin{array}{l}\text { Important } \\
\text { Index \% }\end{array}$} & \multirow{2}{*}{ Ranl } \\
\hline & & & & $\mathrm{F}$ & s & $\mathrm{F}$ & $\mathrm{S} \mathrm{F}$ & & & & & & & \\
\hline F1 & Incomplete Design at The time of Tender & \multirow{8}{*}{ Designer } & 4 & 6 & 3 & 3 & 84 & 100 & 486 & 0.486 & 444 & 0.444 & 21.58 & 5 \\
\hline $\mathrm{F} 2$ & Poor Coordination of Design & & & 1 & 3 & 3 & 46 & 100 & 429 & 0.429 & 363 & 0363 & 15.57 & 20 \\
\hline F3 & $\begin{array}{l}\text { Design change is iritiated due to financial and } \\
\text { economic changes }\end{array}$ & & & 2 & 3 & 4 & 39 & 100 & 442 & 0.442 & 345 & 0345 & 15.25 & 21 \\
\hline $\mathrm{F} 4$ & $\begin{array}{l}\text { Omissions of activity or task from the contract } \\
\text { documentation. }\end{array}$ & & & 4 & 4 & 4 & 91 & 100 & 396 & 0.396 & 448 & 0.448 & 17.74 & 11 \\
\hline F5 & Errors made in the contract documentation & & & 3 & 7 & 4 & 47 & 100 & 517 & 0.517 & 405 & 0.405 & 20.94 & 7 \\
\hline F6 & Insufficient Time to Prepare Contract Documentation & & & 4 & 3 & 4 & $4 \quad 1$ & 100 & 377 & 0.377 & 425 & 0.425 & 16.02 & 17 \\
\hline F7 & $\begin{array}{l}\text { Inadequate Client Brief to Prepare Detailed Contract } \\
\text { Documentation }\end{array}$ & & & 3 & 2 & 2 & 36 & 100 & 381 & 0.381 & 341 & 0341 & 12.99 & 24 \\
\hline F8 & Ineffective Use of Information Technologies & & & 3 & s & 6 & 49 & 100 & 447 & 0.447 & 420 & 0.42 & 18.77 & 9 \\
\hline F9 & Design Change is Initiated by The Contractor & \multirow{8}{*}{ Contractor } & 2 & 3 & 7 & 5 & 69 & 100 & 579 & 0.579 & 443 & 0.443 & 25.65 & 2 \\
\hline $\mathrm{F} 10$ & $\begin{array}{l}\text { Change in construction methods in order to improre } \\
\text { construct-ability or due to site conditions }\end{array}$ & & 3 & 4 & 9 & 9 & $4 \quad 4$ & 100 & 454 & 0.454 & 380 & 0.38 & 17.25 & 14 \\
\hline F11 & Non-compliance with Specification & & & 1 & 6 & 9 & $4 \quad 5$ & 100 & 515 & 0.515 & 463 & 0.463 & 23.84 & 3 \\
\hline F12 & $\begin{array}{l}\text { Machine not working satisfactorily or breakdow nor } \\
\text { defects }\end{array}$ & & 2 & 5 & & 4 & 64 & 100 & 452 & 0.452 & 370 & 0.37 & 16.72 & 15 \\
\hline $\mathrm{F} 13$ & $\begin{array}{l}\text { Omission errors some activity or task by construction } \\
\text { persomel }\end{array}$ & & & 6 & 5 & 4 & $\begin{array}{ll}7 & 4 \\
\end{array}$ & 100 & 491 & 0.491 & 352 & 0352 & 17.28 & 13 \\
\hline F14 & Poor planning and coordination of Resources & & & 1 & trat & 4 & 11 & 100 & 576 & 0.576 & 368 & 0368 & 21.1968 & 6 \\
\hline F15 & Shotage or low skilled of labour & & & 4 & 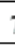 & 5 & 97 & 100 & 462 & 0.462 & 396 & 0396 & 18.30 & 10 \\
\hline F16 & Lack of trairing and experience & & & 5 & 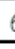 & 6 & 29 & 100 & 428 & 0.428 & 386 & 0386 & 16.52 & 16 \\
\hline F17 & Lack of Coordination and Poor Communication & \multirow{7}{*}{ Orner } & & 4 & 2 & 4 & 83 & 100 & 659 & 0.659 & 514 & 0.514 & 33.87 & 1 \\
\hline F18 & Design change is initiated by the owner & & & 7 & 3 & 4 & 42 & 100 & 517 & 0.517 & 419 & 0.419 & 21.66 & 4 \\
\hline $\mathrm{F} 19$ & $\begin{array}{l}\text { Lack of experience and know ledge of the design and } \\
\text { construction process }\end{array}$ & & & 3 & 7 & 10 & 34 & 100 & 497 & 0.497 & 417 & 0.417 & 20.72 & 8 \\
\hline $\mathrm{F} 20$ & Lack of funding allocated for site inrestigations & & & 2 & $\varepsilon$ & 7 & 76 & 100 & 441 & 0.441 & 401 & 0.401 & 17.68 & 12 \\
\hline F21 & Lack of client inrolvement in the project & & & 3 & 5 & 0 & 13 & 100 & 432 & 0.432 & 366 & 0366 & 15.81 & 18 \\
\hline $\mathrm{F} 22$ & $\begin{array}{l}\text { Insufficient time and money spent on the briefing } \\
\text { process }\end{array}$ & & & 3 & 4 & 4 & 23 & 100 & 355 & 0.355 & 367 & 0367 & 13.03 & 23 \\
\hline $\mathrm{F} 23$ & $\begin{array}{l}\text { Expenditure on low fes for preparing contract } \\
\text { documentation }\end{array}$ & & & 3 & , & 4 & 34 & 100 & 411 & 0.411 & 357 & 0357 & 14.67 & 22 \\
\hline
\end{tabular}

Table 8 Rank of All changes and Highlights the Most Important Eight Changes

\begin{tabular}{|c|c|l|c|c|c|c|c|c|c|}
\hline Rank & $\begin{array}{c}\text { Change } \\
\text { No. }\end{array}$ & $\begin{array}{c}\text { Changes Causing Reworks } \\
\text { of Construction } \\
\text { Downstream Activities }\end{array}$ & $\begin{array}{c}\text { Changes } \\
\text { Category }\end{array}$ & $\begin{array}{c}\text { Total Score } \\
\text { of Severity }\end{array}$ & $\begin{array}{c}\text { Severity } \\
\text { Index }\end{array}$ & $\begin{array}{c}\text { Total } \\
\text { Score of } \\
\text { Frequency }\end{array}$ & $\begin{array}{c}\text { Frequency } \\
\text { Index }\end{array}$ & $\begin{array}{c}\text { Important } \\
\text { Index \% }\end{array}$ & Weight \\
\hline 1 & F18 & $\begin{array}{l}\text { Lack of Coordination and } \\
\text { Poor Communication }\end{array}$ & Owner & 659 & 0.659 & 514 & 0.514 & 33.87 & 100.00 \\
\hline 2 & F9 & $\begin{array}{l}\text { Design Change is Initiated } \\
\text { by The Contractor }\end{array}$ & Contractor & 579 & 0.579 & 443 & 0.443 & 25.65 & 75.73 \\
\hline 3 & F11 & $\begin{array}{l}\text { Non-compliance with } \\
\text { Specification }\end{array}$ & Contractor & 515 & 0.515 & 463 & 0.463 & 23.84 & 70.40 \\
\hline 4 & F19 & $\begin{array}{l}\text { The design change is } \\
\text { initiated by the owner }\end{array}$ & Owner & 517 & 0.517 & 419 & 0.419 & 21.66 & 63.96 \\
\hline 5 & F1 & $\begin{array}{l}\text { Incomplete Design at The } \\
\text { time of Tender }\end{array}$ & Designer & 486 & 0.486 & 444 & 0.444 & 21.58 & 63.71 \\
\hline
\end{tabular}


Hossam H. Mohamed, Ahmed H. Ibrahim and Asmaa A. Soliman

\begin{tabular}{|c|c|c|c|c|c|c|c|c|c|}
\hline 6 & F14 & $\begin{array}{l}\text { Poor planning and } \\
\text { coordination of Resources }\end{array}$ & Contractor & 576 & 0.576 & 368 & 0.368 & 21.20 & 62.58 \\
\hline 7 & F5 & $\begin{array}{l}\text { Errors made in the contract } \\
\text { documentation }\end{array}$ & Designer & 517 & 0.517 & 405 & 0.405 & 20.94 & 61.82 \\
\hline 8 & F20 & $\begin{array}{l}\text { Lack of experience and } \\
\text { knowledge of the design and } \\
\text { construction process }\end{array}$ & Owner & 497 & 0.497 & 417 & 0.417 & 20.72 & 61.19 \\
\hline 9 & F8 & $\begin{array}{l}\text { Ineffective Use of } \\
\text { Information Technologies }\end{array}$ & Designer & 447 & 0.447 & 420 & 0.42 & 18.77 & 55.43 \\
\hline 10 & F15 & $\begin{array}{l}\text { Shortage or low skilled of } \\
\text { labor }\end{array}$ & Contractor & 462 & 0.462 & 396 & 0.396 & 18.30 & 54.02 \\
\hline 11 & $\mathrm{~F} 4$ & $\begin{array}{l}\text { Omissions of activity or task } \\
\text { from the contract } \\
\text { documentation }\end{array}$ & Designer & 396 & 0.396 & 448 & 0.448 & 17.74 & 52.38 \\
\hline 12 & F13 & $\begin{array}{l}\text { Omission errors some } \\
\text { activity or task by } \\
\text { construction personnel }\end{array}$ & Contractor & 491 & 0.491 & 352 & 0.352 & 17.28 & 51.03 \\
\hline 13 & F10 & $\begin{array}{l}\text { Change in construction } \\
\text { methods to improve } \\
\text { construct-ability or due to } \\
\text { site conditions }\end{array}$ & Contractor & 454 & 0.454 & 380 & 0.38 & 17.25 & 50.94 \\
\hline 14 & F12 & $\begin{array}{l}\text { Machine not working } \\
\text { satisfactorily or breakdown } \\
\text { or defects }\end{array}$ & Contractor & 452 & 0.452 & 370 & 0.37 & 16.72 & 49.38 \\
\hline 15 & F16 & $\begin{array}{l}\text { Lack of training and } \\
\text { experience }\end{array}$ & Contractor & 428 & 0.428 & 386 & 0.386 & 16.52 & 48.78 \\
\hline 16 & F6 & $\begin{array}{l}\text { Insufficient Time to Prepare } \\
\text { Contract Documentation }\end{array}$ & Contractor & 377 & 0.377 & 425 & 0.425 & 16.02 & 47.31 \\
\hline 17 & F22 & $\begin{array}{l}\text { Lack of client involvement } \\
\text { in the project }\end{array}$ & Owner & 432 & 0.432 & 366 & 0.366 & 15.81 & 46.68 \\
\hline 18 & F17 & $\begin{array}{l}\text { Problems associated with } \\
\text { multi-layered } \\
\text { subcontracting }\end{array}$ & Contractor & 383 & 0.383 & 408 & 0.408 & 15.63 & 46.14 \\
\hline 19 & F2 & $\begin{array}{l}\text { Poor Coordination of } \\
\text { Design }\end{array}$ & $\begin{array}{l}\text { Designer } \\
\text { Related } \\
\text { Problems } \\
\end{array}$ & 429 & 0.429 & 363 & 0.363 & 15.57 & 45.98 \\
\hline 20 & F3 & $\begin{array}{l}\text { The design change is } \\
\text { initiated due to financial and } \\
\text { economic changes }\end{array}$ & Designer & 442 & 0.442 & 345 & 0.345 & 15.25 & 45.02 \\
\hline 21 & F24 & $\begin{array}{l}\text { Expenditure on low fees for } \\
\text { preparing contract } \\
\text { documentation }\end{array}$ & Owner & 411 & 0.411 & 357 & 0.357 & 14.67 & 43.32 \\
\hline 22 & F23 & $\begin{array}{l}\text { Insufficient time and money } \\
\text { spent on the briefing process }\end{array}$ & Owner & 355 & 0.355 & 367 & 0.367 & 13.03 & 38.47 \\
\hline 23 & F7 & $\begin{array}{l}\text { Inadequate Client Brief to } \\
\text { Prepare Detailed Contract } \\
\text { Documentation }\end{array}$ & Designer & 381 & 0.381 & 341 & 0.341 & 12.99 & 38.36 \\
\hline
\end{tabular}

\section{CONCLUSIONS}

Based on a survey among the different construction experts in Egypt, the most important factors affecting cost contingency were: Importance Index (Relative significance index scores) were developed for the factors identified to be affecting the time rework contingency estimation. According to these Importance Index, the most eight effective factors affecting the estimation of cost contingencies are

- Lack of coordination and poor communication,

- The contractor instruction to modify a design, 
- Non-compliance with the specification,

- The owner instruction to modify a design,

- Incomplete design at the time of tender,

- Poor planning and coordination of resources,

- Errors made in the contract documentation and

- Lack of experience and knowledge of the design and construction process.

It is recommended to avoid the disputable claims the following:

- Owners need to effectively manifest their needs and requirements before designs are conducted.

- The need for training of construction Stakeholders on construction rework and other Variables that causes Projects to overshoot The Budget, time and another resource. Consultants need to give special care to the review and approval of shop drawings.

- Make sure that everyone understands the contractual notice provision.

- Owners, contractors, designers, etc. must be aware of the notice provision in the contract document.

- Recognize that a "risk-sharing" philosophy will probably produce the lowest overall project cost for the owner and maximum profit to the Contractor

\section{DECLARATION}

This paper is based on Ph.D. prepared by the third author (corresponding author) and under the supervision of the first two authors.

\section{REFERENCES}

[1] PMBOK," A Guide to the Project Management Body of Knowledge", Third Edition, 2004.

[2] Jason M. Dougherty and James G. Zack. "The Impact of Rework on Construction \& Some Practical Remedies". Navigant Construction Forum, 2012.

[3] Eze E. C. and Idiake J. E. "Impact of Rework on Building Project and Organization Performance: A View of Construction Professionals in Nigeria" International Journal of Sustainable Construction Engineering \& Technology, Vol. 9 (1), 2018.

[4] Vanhoucke, M., "Project Management with Dynamic Scheduling: Baseline Scheduling, Risk Analysis, and Project Control". 2nd Edition, Springer Heidelberg New York Dordrecht London, 2012.

[5] Abeku, D. M., Ogunbode, E. B., Salihu, C., Maxwell, S. S. and Kure, A., "Projects Management and the effect of Rework on Construction Works: A Case of Selected Projects in Abuja Metropolis, Nigeria" International Journal of Finance and Management in Practice, Vol. 4(1), 2017.

[6] Musa S., and Obaju B., "Effects of Design Errors on Construction Projects" International Journal of Scientific \& Engineering Research, Vol. 7(2), 2016.

[7] Dosumu O S., Idoro G. I., Onukwube H. N., "Causes of Errors in Construction Contract Documents in Southwestern Nigeria"

[8] Journal of Construction Engineering and Management, Vol.5 (1). 2017.

[9] Sen A., Dwivedi, A.K. Trivedi, M.K., "Evaluation of Rework Factors Affecting Cost and Schedule Performance in Construction Projects" International Research Journal of Engineering and Technology (IRJET), Vol. 5 (8), pp.56-72, 2018.

[10] Enshassi A., Sundermeier, M., and Abo Zeiter, M.. "Factors Contributing to Rework and their Impact on Construction Projects Performance".International Journal of Sustainable Construction Engineering \& Technology, Vol. 8(1), 2017. 
[11] Love P. E. D., Zahir I., and Edwards D. J. "A rework reduction model for construction projects" IEEE Transactions on Engineering Management, Vol.51 (4), pp. 426-440, 2004.

[12] Jing Liu, and Ming Lu, "Hierarchical Multi-Project Planning and Supply Chain Management: an Integrated Framework", Journal of Construction Engineering and Management, 2018.

[13] RazaviAlavi1 S., and AbouRizk S., "Site Layout and Construction Plan Optimization Using an Integrated Genetic Algorithm Simulation Framework", Journal of Construction Engineering and Management, 2017.

[14] Arashpour M., R. Wakefield, N. Blismas, and J. Minas, "Optimization of process integration and multi-skilled resource utilization in offsite construction" Autom. Constr. 50 (Feb): 72-80, 2015.

[15] El-Abbasy M., S., "Multi-Objective Multi-Project Construction Scheduling Optimization", Ph.D., Concordia University, Canada, 2015.

[16] Pakgohar A., "Hierarchical Multi-Project Planning and Supply Chain Management: an Integrated Framework", Ph.D., Exeter University, Canada, 2014.

[17] Chen P., H., and Weng, H., "A two-phase GA model for resource-constrained project scheduling School of Civil and Environmental Engineering, Nanyang Technological University, Singapore, Automation in Construction, www. elsevier.com/locate/autcon, 2009.

[18] Soliman, A. A. (Incomplete), "Optimizing Project Cost and Schedules under Resource Constraints". Ph.D., Zagazig University, Egypt, 2020.

[19] Aman S., Dwivedi A.K. and Trivedi M.K. "Evaluation of Rework Factors Affecting Cost and Schedule Performance in Construction Projects" International Research Journal of Engineering and Technology, Vol. 5 (8), 2018

[20] Wakefield A., N. Blismas N. and Minas J., "Optimization of process integration and multiskilled resource utilization in offsite construction." Autom. Constr., 2015.

[21] Mohammad B. and Majid G "Reworks causes and related costs in construction: case of Parand mass housing project in Iran" International Journal of Quality \& Reliability Management, Vol. $36(8), 2019$.

[22] Easterby-Smith, M., Thorpe, R. and Lowe, A, "Management research: an introduction ", SAGE publications Ltd, 2002.

\section{APPENDIX}

\section{Questionnaire Survey}

In this survey, the factors that arising in the upstream Activities and Causing Reworks in the downstream Activities are categorized into three main categories as follow:

- The Owner Related Changes.

- The Designer Related Changes.

- The Contractor Related Changes.

The rework time values are allocated to each factor depending on the degree of overlapping between each pair of activities. The degree of overlapping (duration of overlapping) will be a percentage of the smallest duration of the upstream and downstream activities.

\section{Note}

Please give a rank number for each factor to reflect its significance, Time as Frequency, where 0 indicates lack of factor's Frequency and from 1 to 10 indicates no. of Frequency for each factor, Time as factor Severity, where 0 indicates lack of factor and from 1 to 10 indicates to the value of factor Severity 
Construction Factors That Causing Reworks in Downstream Activities Due to Overlapping

\section{Questionnaire Survey Design}

\begin{tabular}{|c|c|c|c|c|}
\hline $\begin{array}{l}\text { Factor } \\
\text { No. }\end{array}$ & $\begin{array}{l}\text { Changes of Predecessor Activities that } \\
\text { Causing Reworks in Downstream } \\
\text { Activities Due to Period Overlapping }\end{array}$ & $\begin{array}{l}\text { Problem } \\
\text { Category }\end{array}$ & $\begin{array}{c}\text { Severity on Causing } \\
\text { Rework in Downstream } \\
\text { Activities (0 T0 10) }\end{array}$ & $\begin{array}{l}\text { The Probability of } \\
\text { Occurrence of } \\
\text { Rework (0 T0 10) }\end{array}$ \\
\hline F1 & Incomplete Design at the time of tender. & \multirow{8}{*}{$\begin{array}{l}\text { Designer } \\
\text { Related } \\
\text { Changes }\end{array}$} & & \\
\hline F2 & Poor Coordination of design. & & & \\
\hline F3 & $\begin{array}{l}\text { Design change is initiated due to financial } \\
\text { and economic changes. }\end{array}$ & & & \\
\hline F4 & $\begin{array}{l}\text { Omissions of activity or task from the } \\
\text { contract documentation. }\end{array}$ & & & \\
\hline F5 & Errors made in the contract documentation. & & & \\
\hline F6 & $\begin{array}{l}\text { Insufficient time to prepare contract } \\
\text { documentation. }\end{array}$ & & & \\
\hline F7 & $\begin{array}{l}\text { Inadequate client brief to prepare detailed } \\
\text { contract documentation. }\end{array}$ & & & \\
\hline F8 & Ineffective use of information technologies. & & & \\
\hline F9 & $\begin{array}{l}\text { The contractor instruction to modify a } \\
\text { design }\end{array}$ & \multirow{9}{*}{$\begin{array}{l}\text { Contractor } \\
\text { Related } \\
\text { Changes }\end{array}$} & & \\
\hline F10 & $\begin{array}{l}\text { The contractor instruction to modify a } \\
\text { construction methods }\end{array}$ & & & \\
\hline F11 & Non-compliance with specification. & & & \\
\hline F12 & $\begin{array}{l}\text { The contractor instruction to modify a } \\
\text { construction methods }\end{array}$ & & & \\
\hline F13 & Machine breakdown and defects & & & \\
\hline F14 & Poor planning and coordination of resources. & & & \\
\hline F15 & $\begin{array}{l}\text { Omission errors some activity or task by } \\
\text { construction personnel. }\end{array}$ & & & \\
\hline F16 & Unqualified work force in the project & & & \\
\hline F17 & Lack of training and experience. & & & \\
\hline F18 & $\begin{array}{l}\text { Lack of coordination and poor } \\
\text { communication. }\end{array}$ & \multirow{6}{*}{$\begin{array}{c}\text { Owner } \\
\text { Related } \\
\text { Changes }\end{array}$} & & \\
\hline F19 & The owner instruction to modify a design & & & \\
\hline F20 & $\begin{array}{l}\text { Lack of experience and knowledge of the } \\
\text { design and construction process. }\end{array}$ & & & \\
\hline F21 & $\begin{array}{l}\text { Lack of funding allocated for site } \\
\text { investigations. }\end{array}$ & & & \\
\hline F22 & Lack of client involvement in the project. & & & \\
\hline F23 & $\begin{array}{l}\text { Insufficient time and money spent on the } \\
\text { briefing process. }\end{array}$ & & & \\
\hline
\end{tabular}

